\title{
Genetic diversity of the Brazilian Creole cattle Pé-duro assessed by microsatellites and mitochondrial DNA ${ }^{1}$
}

\section{Ana Paula Ferreira de Oliveira ${ }^{2}$, José Herculano de Carvalho ${ }^{3}$, Marcos Mateo Miretti ${ }^{4}$, Maria Aparecida Cassiano Lara ${ }^{5}$, Eucleia Primo Betioli Contel ${ }^{2}$}

\author{
${ }^{1}$ Financially supported by Conselho Nacional de Desenvolvimento Científico e Tecnológico (CNPq). \\ 2 Departamento de Genética, Faculdade de Medicina de Ribeirão Preto, Universidade de São Paulo, SP, Brazil. \\ ${ }^{3}$ Associação Brasileira de Criadores de Gado Pé-Duro (ABCPD), Teresina, Pl, Brazil. \\ ${ }^{4}$ Depto de Genética, FCEQyN, Universidad Nacional de Misiones, Argentina. \\ ${ }^{5}$ Instituto de Zootecnia, Nova Odessa, SP, Brazil.
}

\begin{abstract}
The objective of this study was to describe the genetic diversity and structure of the largest Pé-duro population by assessing variation at ten autosomal microsatellite (STR) loci and mitochondrial DNA (mtDNA) sequences. The mean expected heterozygosity was 0.755 , the mean observed heterozygosity was 0.600 and significant inbreeding coefficient (Fis) and deviations from the Hardy-Weinberg equilibrium in most of analyzed loci demonstrate the impact of inbreeding and homozygosis on this population. A more in-depth genetic analysis could be achieved by expanding the STR list. The analysis of mtDNA provided evidence of ancestral African taurine haplotypes in Pé-duro and excluded maternal Zebuine introgression. In this report, the main Pé-duro population is genetically portrayed by sampling approximately $40 \%$ of it. As this herd represents the core of the Pé-duro conservation program, these findings are of outstanding value for the management and preservation of this Brazilian 'native' cattle breed.
\end{abstract}

Key Words: Bos taurus, cattle, conservation, genetic diversity, microsatellites, mitochondrial DNA

\section{Introduction}

Historically, Bos taurus cattle was introduced in the Americas during the first 100 years of colonization by the Portuguese and Spanish settlements. For over 400 years, descendants of this original group of animals evolved under natural selection in small populations dispersed over a variety of environments, adapted to different ecological niches almost without human interference (Mariante \& Cavalcante, 2006; Mariante et al., 2009; Primo, 1992). Specifically, in dry regions of the Brazilian northern states, the Pé-duro Creole or Curraleira breed emerged, adapting to adverse conditions present in this semi-arid region, endowing these animals with extremely rustic features such as lighter weight, resistance to drought, heat, low quality ranges, poor nutrition and lack of health care. This breed is raised in small herds and its total population size is very small mainly because the Pé-duro males were systematically castrated and replaced by zebu (Bos indicus) bulls in the early 20th century. According to Associação Brasileira de Criadores de Gado Pé-duro - ABCPD (http://abcpd.com.br), in the XVIII century, the Piauí State owned the largest cattle herd in Brazil, becoming a major exporter of meat to the other Brazilian regions. In the same century, about 30,000 heads of all cattle were slaughtered every year in Parnaíba city, Piauí State, and Pé-duro was the basis of this livestock farming. Currently, there are about 1,500 cattle distributed in the northeast of Brazil. Specifically in the Agricultural Research Center for the Mid-North (Embrapa Meio-Norte), there are currently 300 individuals. This nearly wiped out this breed and could be dangerously smaller if effective actions to preserve this breed are not taken (Britto, 1998; Carvalho, 1985; Carvalho et al., 2001).

Experimental results on the productivity of the Pé-duro breed and its crossbreeds are extremely scarce, which makes it difficult to evaluate their economic potentiality. The Pé-duro and its crossbreeds can be an option for the exploitation of wide lands in north-eastern Brazil. On cultivated pastures, some cattle raisers have gotten promising results in beef production by crossing Pé-duro and Nellore or Gyr breeds. The average carcass weight of the half-blood was $203.4 \mathrm{~kg}$ at 3.5 years of age, and the maximum value of $284.0 \mathrm{~kg}$ in Pé-duro-Gyr (Carvalho, 2002).

To contribute to the maintenance of this valuable genetic resource, the current Agricultural Research Center for the Mid-North (Embrapa Meio-Norte) established, in 1983, a herd to preserve the Pé-duro breed in Piaui, Brazil. Current phenotypic and genetic data available from 
this population are rather scarce; a coordinated effort to delineate the genetic profile is critical to the success of the conservation program. Further investigating the origin of mtDNA haplotypes (mtDNA control region sequence) in a small survey revealed the presence of an ancestral African mtDNA haplotype.

The objective of this study was to assess the genetic diversity in this Pé-duro core population and derive descriptive population genetic parameters from autosomal STR loci.

\section{Material and Methods}

The study was conducted using DNA samples from animals of both sexes $(n=126)$ collected from a Pé-duro herd held at the Octavio Domingues Experimental Farm, in São João do Piaui, state of Piauí, Brazil (coordinates $8^{\circ} 26^{\prime}$ and $8^{\circ} 54^{\prime}$ south, $42^{\circ} 19^{\prime}$ and $42^{\circ} 45^{\prime}$ west). This farm belongs to the Agricultural Research Center for the MidNorth (Embrapa Meio-Norte), a branch of the Brazilian Organization for Agricultural Research (Embrapa). In 2004, approximately 350 animals constituted this population. These animals graze freely far from human settlings during most of the 'rainy' season, gathering together close to the main water source during the dry season, thus opening a management opportunity. Consequently, genealogy records are not complete and possibly inaccurate, mostly based on the identification of few mating bulls at a given time.
This management condition may well affect the population genetics analyses, but sampling nearly $40 \%$ of the current population will, however, provide a reliable proxy to the actual genetic structure of this Pé-duro population.

Genomic DNA was extracted following the method of Higuchi (1989) and used as template for PCR amplification of microsatellite loci and mtDNA. Ten informative microsatellite markers - SPS115, BM1824, BM2113, BMS4049, TGLA122, ETH225, ETH10, INRA23, UWCA46 and BMS348 (Table 1) - were selected and genotyped according to available data from local cattle breeds; seven of them derived from the FAO-ISAG recommended list. The PCR was performed in thermocycler (Robocycler 40 Stratagene) with $25 \mu \mathrm{L}$ final volume containing $1 \mathrm{X}$ PCR buffer with $200 \mathrm{ng}$ genomic DNA, and using different amplification conditions (Table 2). Only primers SPS115, BM1824 and BM2113 had better amplification using two annealing temperatures in the DNA amplification by Touchdown PCR for increased specificity and sensitivity in PCR amplification. Touchdown PCR is a modification of conventional PCR that may result in a reduction of nonspecific amplification. It involves the use of an annealing temperature that is higher than the target optimum in early PCR cycles. The annealing temperature is decreased by $1{ }^{\circ} \mathrm{C}$ every cycle or every two cycles until a specified or 'touchdown' annealing temperature is reached. The touchdown temperature is used for the remaining number of cycles. This enables the enrichment of the correct product

Table 1 - Details of the primer sequences for ten microsatellite loci from the Pé-duro population

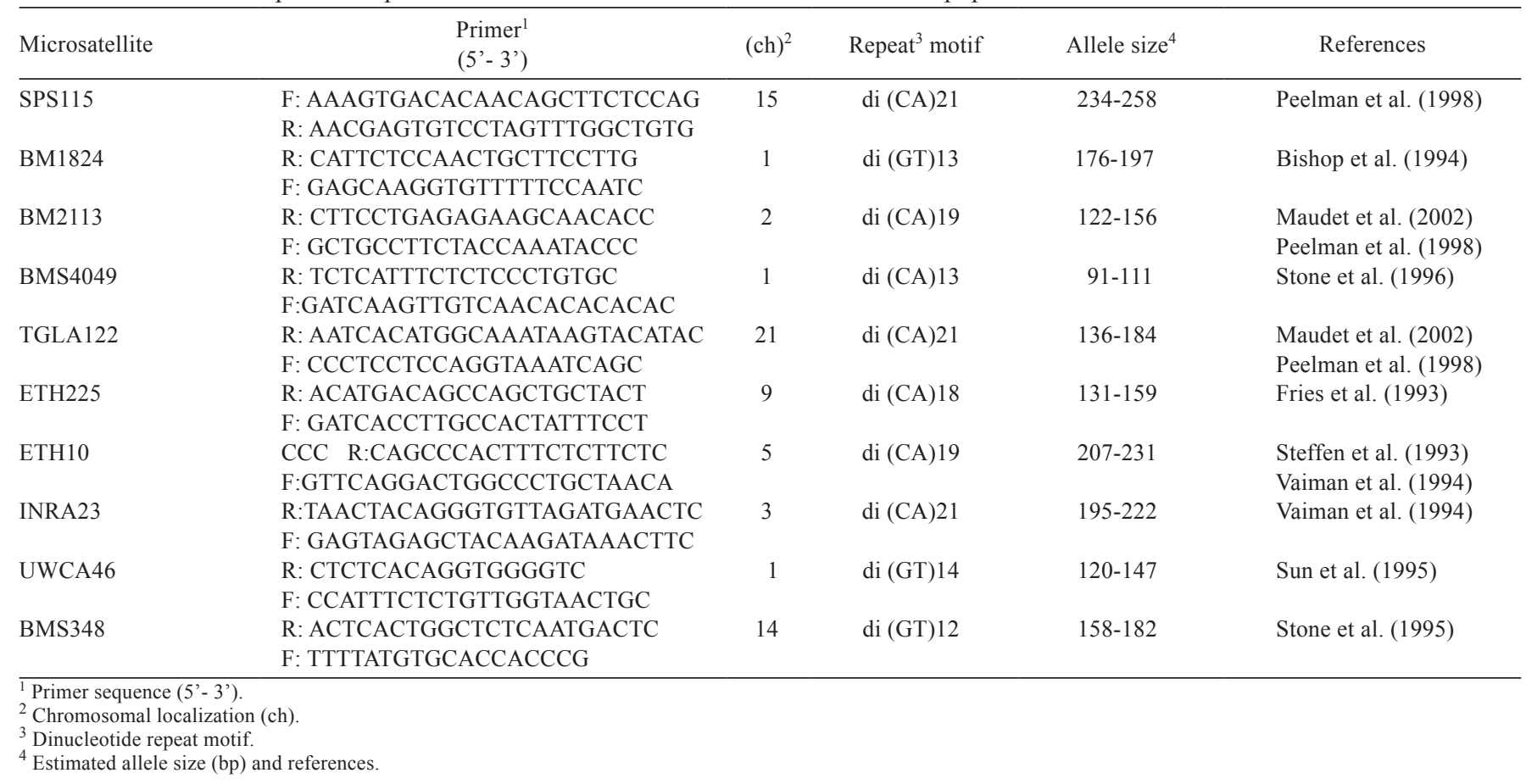


Table 2 - PCR amplification conditions for a reaction of the microsatellites analyzed

\begin{tabular}{lccccc}
\hline Microsatellites & $\begin{array}{c}\mathrm{Tm}^{\circ} \\
\left({ }^{\circ} \mathrm{C}\right)\end{array}$ & $\begin{array}{c}\mathrm{MgCl} 2 \\
(\mathrm{mM})\end{array}$ & $\begin{array}{c}\text { Primer } \\
(\mu \mathrm{M})\end{array}$ & $\begin{array}{c}\mathrm{dNTP} \\
(\mu \mathrm{M})\end{array}$ & $\begin{array}{c}\text { Taq DNA } \\
(\mathrm{U} / \mu \mathrm{L})\end{array}$ \\
\hline SPS115 & $58-63$ & 1.5 & 0.175 & 200 & 0.5 \\
BM1824 & $58-63$ & 1.5 & 0.150 & 200 & 0.5 \\
BM2113 & $58-63$ & 1.5 & 0.175 & 200 & 0.5 \\
BMS4049 & 55 & 3.0 & 0.150 & 200 & 0.5 \\
TGLA122 & 45 & 3.0 & 0.180 & 200 & 0.5 \\
ETH225 & 57 & 3.0 & 0.150 & 200 & 0.5 \\
ETH10 & 55 & 3.0 & 0.100 & 200 & 0.5 \\
INRA23 & 50 & 4.0 & 0.200 & 200 & 0.5 \\
UWCA46 & 57 & 4.0 & 0.150 & 200 & 0.3 \\
BMS348 & 58 & 4.0 & 0.150 & 200 & 0.3 \\
\hline
\end{tabular}

Temperature annealing (Tmo), $\mathrm{MgCl} 2$ concentration $(\mathrm{mM})$, primer concentration $(\mu \mathrm{M})$, concentration of each dNTP, Taq DNA polymerase.

over any non-specific product. The following amplification protocol for these specific primers was adopted: $94^{\circ} \mathrm{C}$ for $5 \mathrm{~min} ; 5$ cycles of $1 \mathrm{~min}$ at $94{ }^{\circ} \mathrm{C}$; and $63{ }^{\circ} \mathrm{C} ; 1 \mathrm{~min}$ at $72{ }^{\circ} \mathrm{C}$; 30 cycles of $1 \mathrm{~min}$ at $94{ }^{\circ} \mathrm{C}$; and $58{ }^{\circ} \mathrm{C} ; 1 \mathrm{~min}$ at $72{ }^{\circ} \mathrm{C}$ and 10 min at $72{ }^{\circ} \mathrm{C}$. The amplification protocol of others primers was $94{ }^{\circ} \mathrm{C}$ for $1 \mathrm{~min} ; 30$ cycles of $1 \mathrm{~min}$ at $94{ }^{\circ} \mathrm{C}$; $55{ }^{\circ} \mathrm{C} ; 45^{\circ} \mathrm{C}$; and $57{ }^{\circ} \mathrm{C} ; 1 \mathrm{~min}$ at $72{ }^{\circ} \mathrm{C}$; and 10 to $20 \mathrm{~min}$ at $72{ }^{\circ} \mathrm{C}$ (Table 2). The amplified products were subjected to electrophoresis in polyacrylamide $12 \%$ denaturing and $10 \%$ non-denaturing gels and visualized by silver-staining. The estimated size in base pairs (bp) in the denaturing and non-denaturing gel was obtained using the molecular marker DNA Ladder of molecular weight $25 \mathrm{pb}$ and $50 \mathrm{pb}$ (Invitrogen).

A $1 \mathrm{~kb}$ DNA fragment comprising the hypervariable region of the mtDNA control region (CR) was amplified in 11 Pé-duro individuals. The effective population size of mtDNA is one quarter that of diploid nuclear genes so haplotype frequencies can drift rapidly, creating differences in relatively short times among other populations. The mutational dynamics of mtDNA sequences enable the genetic relationships among haplotypes to be inferred. Argentinean Creole $(\mathrm{n}=12)$ and Brazilian native cattle breeds Pé-duro ( $n=11)$, Caracu $(n=8)$, Mocho Nacional $(n=6)$ and Pantaneiro $(n=10)$ were analyzed according to Miretti et al. (2002). Details regarding PCR amplification, sequencing reactions and primers sequence were previously reported by Miretti et al. (2004). Each consensus sequence (450 bp) was derived from the alignment of at least one sequence read in each sense. Substitutions within a $240 \mathrm{bp}$ fragment (16023-16262) of the mtDNA control region were checked and polymorphic sites were identified by direct comparison with the $B$. taurus mtDNA reference sequence (Anderson et al., 1982), namely the European consensus (Eucons), the African-derived AA1 haplotype described in other native cattle breeds except Pé-duro (Miretti et al., 2002) and the
B. indicus mtDNA reference sequence (NCBI - Genome Project and Miretti et al., unpublished data, Bos indicus mitochondrion, complete genome: http://www.ncbi.nlm. nih.gov/nuccore/NC_005971.1).

Allele frequencies at each locus were estimated by direct counting in the Pé-duro population and used to calculate deviations from the Hardy-Weinberg equilibrium employing the program GENEPOP, version 2.0 (Raymond $\&$ Rousset, 1995). The comparison of the allele frequency distribution was performed using Fisher's exact test. Three tests were conducted based on null hypothesis of random union of gametes: the overall probability exact test, test for the detection of disability and test for the detection of excess of heterozygotes. In all tests, the P value was obtained using the procedure of Markov chains. The GDA program (Lewis \& Zaykin, Genetic data analysis: software for the analysis of discrete genetic data. 1997, version 1.0) was used to estimate the intralocus expected $(\mathrm{He})$, observed ( $\mathrm{Ho})$ and average heterozygosity. To investigate the intensity of inbreeding, the within population inbreeding coefficient (Fis) was estimated at each locus according to formula developed by Nei (1987). The F (Fis) statistic was performed by the statistical significance (Bootstrappingconfidence interval). Allelic richness is a measure of genetic variation in the average number of alleles per locus or allelic diversity. The observed number of alleles in a sample is highly dependent on sample size. To avoid this problem, El Mousadik \& Petit (1996) suggested adapting the rarefaction index of Hurlbert (1971) for population genetics (Petit et al., 1998). The allelic richness, in which $\mathrm{R}$ is the estimate of allelic richness per locus and per sample, was calculated by the program FSTAT (Goudet, version 2.9.3, 2001), a program to estimate and test gene diversities and fixation indices, available at http://www2.unil.ch/popgen/ softwares/fstat.htm. The principle is to calculate the expected number of alleles in a sample of $2 \mathrm{n}$ genes given that $2 \mathrm{~N}$ genes have been sampled $(N \geq n) . N_{i}$ is the number of alleles of type $\mathrm{i}$ among the $2 \mathrm{~N}$ genes, and $\mathrm{n}$ is fixed as the smallest number of individuals typed for a locus in a sample. According to Leberg (2002), it is necessary to standardize and fix the value of $\mathrm{n}$ because the comparison between different sample sizes of several different studies would become complicated. In this study, the fixed value of $n$ was considered as a diploid individual $(n=1)$, i.e., the probability of an allele being represented at least once in a sample of an individual $2 \mathrm{n}$, thus allowing a real comparison with the study of Sastre (2003). The Pic (polymorphism information content) values for each microsatellite marker were calculated using software Cervus version 3.0.3 (Marshall et al., 1998). 


\section{Results and Discussion}

Allele frequencies estimates in a population sample are determined by its size and other factors inherent to the population such as mutation rate and gene flow. Following of considerations Hedrick (2005), a sample size of $>100$ individuals was set to derive reliable microsatellite data. Our population sample $(n=126)$ is therefore appropriate. However, an increased number of microsatellites (genomic sampling) could be necessary to gain more in-depth genetic data analyses.

The number of alleles per locus ranged from 5 to 20 with a mean number of 10.1, except for locus BMS348, (Table 3), which is in line with the diversity parameters recommended by FAO (Fao, 2004) suggesting at least five alleles per locus to be considered a good genetic variability indicator. In a total of 101 alleles, the average allelic richness value found was 1,748, ranging from 1,455 in BMS4049 to 1,912 in TGLA122 and UWCA46. Similar number of alleles (average 8.2), gene diversity (average 0.813 ) and allelic richness (average 1.76) values have been described in the Casanare breed, from Colombia (Sastre, 2003), a Creole isolated cattle breed adapted to their local environment.

An appropriate measure of genetic variation in populations related to the effective number of alleles is the gene diversity of Nei (1987) or average heterozygosity. The Pé-duro population shows high genetic diversity values in each locus, with an average of 0.756 . However, overall, all loci showed higher expected heterozygosity values (average 0.755 ) and the observed heterozygosity (average 0.600) (Table 3), as also reported for the Mexican Creole breed (Ulloa-Arvizu et al., 2008).

High Pic values were observed in most loci examined (Table 3); two of them above $90 \%$, indicating extremely high diversity in these polymorphic sites; Pic values greater than 0.50 are considered informative (Hedrick, 2005). Two other loci presented values under 0.50 . The average Pic value in this Pé-duro population was 0.723 and 0.650 , reported by Egito et al. (2004) for the same breed. Values of Pic were observed in other Brazilian native breeds such as Crioula Lageano (0.698) and Pantaneira (0.708) (Egito et al., 2004). Therefore, most loci analyzed in the Péduro population were polymorphic and informative. Some of these highly polymorphic loci in Bos taurus are less informative in B. indicus (Cervini et al., 2006; Egito et al., 2007; Lirón et al., 2006).

The within population inbreeding coefficient (Fis) observed in the Pé-duro population, considering all loci, was significantly higher than expected in a random mating population (average $F i s=0.206, \mathrm{P}<0.01$ ) excluding BM1824 (Table 3).

The analyses performed with microsatellite markers revealed significant deviations of the Hardy-Weinberg equilibrium $(\mathrm{P}<0.01)$ in most of loci analyzed in the exact test, excluding BMS348 (Table 3). Estimation of exact

Table 3 - Genetic diversity for each locus in the Pé-duro population

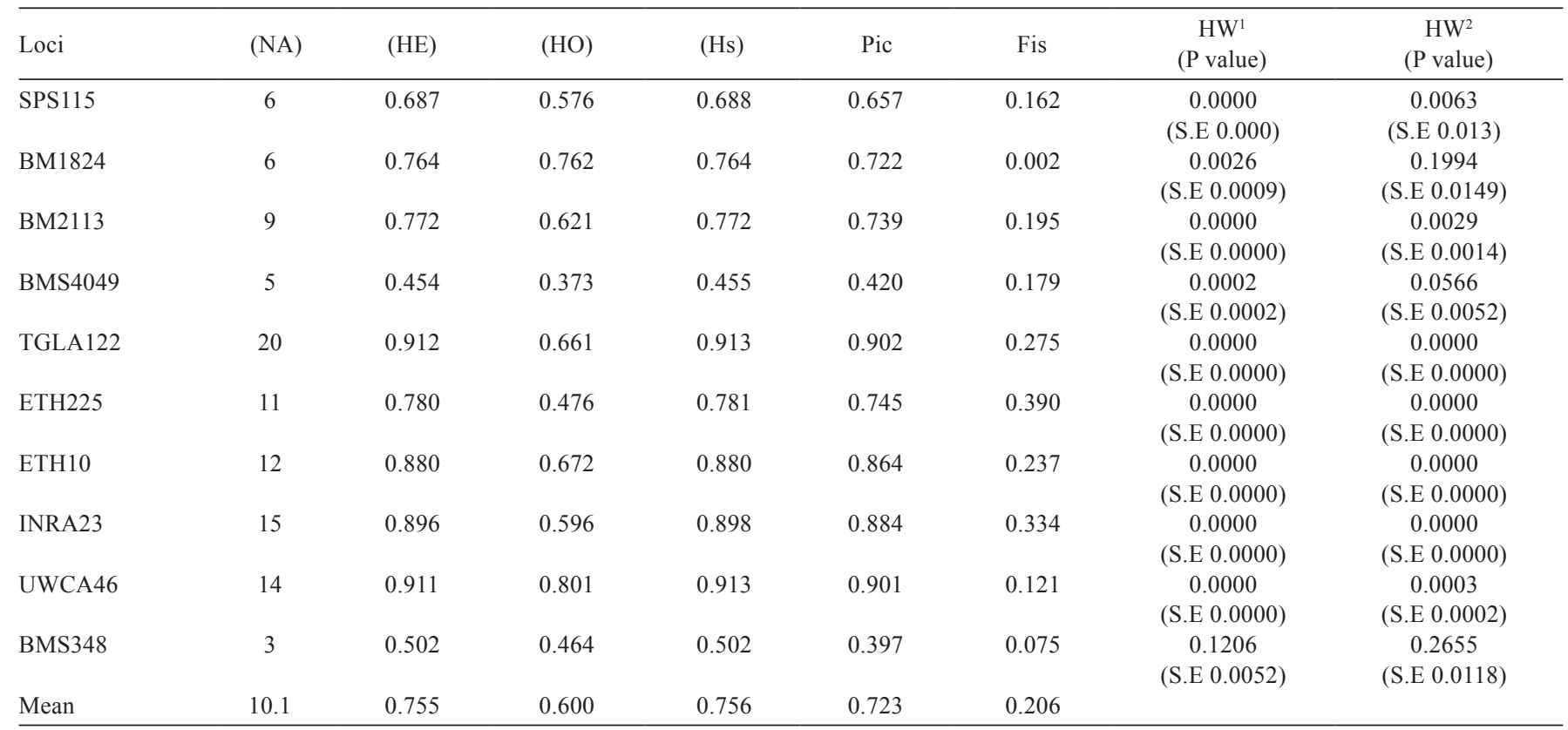

NA - number of alleles; HE - expected heterozygosity; HO - observed heterozygosity; Hs - gene diversity; Pic - polymorphic information content; Fis - inbreeding coefficient value; Hardy-Weinberg exact test $\mathrm{HW}^{1}$ - Hardy-Weinberg heterozygote deficit test HW $\mathrm{HW}^{2}$ and S.E standard error by Fisher's method.

$\mathrm{HW}^{1} \mathrm{HW}^{2}$ Significant deviation $(\mathrm{P}<0.01)$ (Raymond \& Rousset, 1995).

Fis (confidence interval bootstrapping $0.081 / 0.324 \mathrm{P}<0.01$ ). 
$P$ values was performed by the Markov chain method. Bonferroni's correction for multiple tests was applied for parameter estimated significance $(\mathrm{P}<0.01)$ (Table 3$)$. Two tests more sensitive than the Fisher were applied in order to verify if the deviation is caused by heterozygous excess or deficit. These tests indicated significant deviations of the Hardy-Weinberg equilibrium $(\mathrm{P}<0.01)$ due to the lack of heterozygous in seven (SPS115, BM2113, TGLA122, ETH10, ETH225, INRA23, UWCA46) out of the ten loci examined on Hardy-Weinberg 2 (Table 3). This observation is consistent with results reported in genetically isolated and structured populations such as native cattle breeds from Portugal, Spain and France (Beja-Pereira et al., 2003), Brazilian Creole breeds (Caracu, Crioulo Lageano, Curraleiro, Mocho Nacional and Pantaneiro) and other breeds of European origin (Egito et al., 2004). The equilibrium deviation that affects all loci may suggest the occurrence of a series of nonexclusive events such as founder effect inbreeding, subdivision and geographic isolation. The population studied was assumed to be well adapted to its local region with isolation leaving the strongest imprint on loss of genetic variation and inbreeding. The list of microsatellites employed to measure the genetic diversity in this study is widely used in numerous studies.

These results of the Pé-duro can be a direct consequence of the excess of homozygous genotypes, deficiency of heterozygous genotypes and presence of null alleles in this population. High inbreeding rate has been previously reported in the Pé-duro breed by Egito (2007). The large number of homozygotes observed is possibly due to the limited number of bulls available. The whole Péduro population under consideration is rather small ( $\mathrm{N}$ total $\sim 300$ individuals) located in the core conservation Agricultural Research Center of the Mid-North (Embrapa Meio-Norte). Of these 126 individuals, which are an isolated population which reproduced each other and could explain the significant inbreeding found.

A comparative analysis was performed based on the data obtained in this study and those derived from other native breeds (Table 4), e.g. Colombian Creole Casanare (Sastre, 2003), Uruguayan Creole (Armstrong et al., 2006), native Jersey from the Isle of Jersey in the UK (Chikhi et al., 2004), Asian native cattle breeds (Kim et al., 2002) and Portuguese native breeds, encompassing the Alentejana, Arouquesa, Barrosa, Brava de Lide, Garvonesa, Minhota, Mertolenga, Maronesa and Mirandesa (Mateus et al., 2004). Pé-duro was more informative when confronting the average number of alleles in a small set of microsatellites (Table 4). Comparable average $H o$ and $H s$ values were observed between the Pé-duro and the Uruguayan Creole
(Armstrong et al., 2006), with the highest value recorded in Casanare (Table 4).

Several markers show a significant deficit of heterozygotes due to the presence of inbreeding within native cattle populations, in line with records in native breeds from Portugal, Spain and France (Beja-Pereira et al., 2003; Maudet et al., 2002), in Romosinuano Creole from Colombia (Barrera et al., 2006), Creole breeds from Argentina and Bolivia (Lirón et al., 2006) and in Mexican Creole (Ulloa-Arvizu et al., 2008). Inbreeding and loss of diversity represents a major management concern in conservation schemes; inbreeding is, however, unavoidable and natural in all populations (Woolliams et al., 2008). Conservation initiatives involving the Pé-duro breed include the exchange of bulls between farms and various populations on one side, as well as the expansion of germplasm collection and cryopreservation (Egito, 2007). The rate of inbreeding could be managed simultaneously within a selection program to improve their economic viability (Woolliams et al., 2008).

To further characterize the genetic background of the Pé-duro population, $1 \mathrm{~kb}$ of the mtDNA control region was sequenced in 11 Pé-duro individuals, thus expanding our previous survey where only European derived taurine haplotypes were identified in this population (Miretti et al. 2002). Seven European-derived haplotypes identical to those previously reported (3 EA1 and 4 EA2) were found; more interestingly, 4 animals carrying the ancestral African AA1 mtDNA haplotype, already described in most of Brazilian native cattle breeds except Pé-duro, were detected. The origin of this ancestral taurine mtDNA haplotype is still unclear, but it is known that (a) it is closer to the African ancestral consensus (Troy et al., 2001) than to the European ancestral haplotype, and (b) that it is present in South American, Caribbean and Spanish taurine cattle, and in some Nellore animals bearing taurine mtDNA (Meirelles et al., 1999; Miretti et al., 2002; Magee et al., 2002;

Table 4 - Data from Pé-duro and data published for other native cattle breeds sampled per population

\begin{tabular}{|c|c|c|c|c|}
\hline Breeds & NA & $\mathrm{HO}$ & HS & Fis \\
\hline Pé-duro (n=126) & 10.1 & 0.600 & 0.756 & 0.206 \\
\hline Casanare $^{1}(n=54)$ & 8.2 & 0.753 & 0.760 & 0.1547 \\
\hline \multicolumn{5}{|l|}{ Native } \\
\hline Portuguese $^{2}(n=470)$ & 11 & - & - & 0.1551 \\
\hline Uruguay $^{3}(n=19)$ & 4.5 & 0.675 & 0.667 & - \\
\hline \multicolumn{5}{|l|}{ Native } \\
\hline Jersey $^{4}(n=199)$ & 4.5 & 0.635 & 0.633 & 0.060 \\
\hline $\begin{array}{l}\mathrm{n} \text { - number of individual } \\
\text { Hs - gene diversity; Fis - } \\
{ }^{1} \text { Data from Sastre (2003 } \\
{ }^{2} \text { Data from Mateus et al. } \\
{ }^{3} \text { Data from Armstrong e } \\
{ }^{4} \text { Data from Chikhi et al. }\end{array}$ & $\begin{array}{l}\text { A - num } \\
\text { eeding } \\
4) . \\
(2006) . \\
4) .\end{array}$ & $\begin{array}{l}\text { f alleles } \\
\text { ient }(\mathrm{P}\end{array}$ & & rozygos \\
\hline
\end{tabular}


Mirol et al., 2003; Miretti et al., 2004). Briefly, the mtDNA data demonstrate the presence of the African-derived mitochondria and fail to diagnose maternal acquisition of Zebuine genes in this Pé-duro population. However, it would be necessary to evaluate variation in Y chromosome polymorphic systems to confirm the putative male mediated introgression of zebuine genes. Additional details about the phylogeography of mtDNA haplotypes are available in references listed above.

\section{Conclusions}

The genetic characterization of the Pé-duro population based on these data is consistent and comparable to analyses conducted in most of native cattle breeds. Despite the statistically significant inbreeding coefficient and deviations from the Hardy-Weinberg equilibrium observed, genetic diversity in this native Brazilian breed is, however, formidable as demonstrated by gene diversity, heterozygosity values and mtDNA sequence data. The conservation of the Pé-duro breed is crucial as resource for genetic introgression and genetic improvement programs to increase the resistance of commercial flocks to diseases and parasites, key actions for future agriculture. Conservation initiatives are fundamental not only from the scientific point of view, but also for cultural, historical and economical aspects in Brazil.

\section{Acknowledgments}

The authors thank the National Council for Scientific and Technological Development $-\mathrm{CNPq}$ and the Foundation to Support Education, Research and Care of the Hospital of the Medical School of Ribeirão Preto, Universidade de São Paulo - FAEPA for the financial support and scholarship granted.

\section{References}

ANDERSON, S.; DE BRUIJN, M.H.L.; COULSON, A.R. et al. Complete sequence of bovine mitochondrial DNA. Journal Molecular Biology, v.156, p.683-717, 1982.

ARMSTRONG, E.; POSTIGLIONI, A.; MARTÍNEZ, A. et al. Microsatellite analysis of a sample of Uruguayan Creole bulls (Bos taurus). Genetics and Molecular Biology, v.29, n.2, p.267-272, 2006.

BEJA-PEREIRA, A.; ALEXANDRINO, P.; BESSA, I. et al. Genetic characterization of southwestern European bovine breeds: A historical and biogeographical reassessment with a set of 16 microsatellites. Journal of Heredity, v.94, n.3, p.243-250, 2003.

BARRERA, P.G.; MARINEZ, R.; PEREZ, E.J. et al. Evaluación de la variabilidad genética en ganado Criollo Colombiano mediante 12 marcadores microsatélites. Animal Genetic Resources, v.38, p.35-45, 2006.
BISHOP, M.D.; KAPPES, S.M.; KEELE, J.W. et al. A genetic linkage map for cattle. Genetics, v.136, p.619-639, 1994.

BRITTO, C.M.C. Citogenética do gado Pé-duro. Teresina: EDUFPI, 1998. 80p.

CARVALHO, J.H. Pé-duro, patrimônio preservado no Piauí. Dirigente Rural, v.24, p.26-28, 1985.

CARVAlho, J.H. Potencial econômico do bovino Pé-duro. Teresina: Embrapa Meio-Norte, 2002. 14p. (Documentos 65).

CARVALHO, J.H.; MONTEIRO, F.C.; GIRÃO, R.N. Conservação do bovino Pé-duro ou curraleiro: situação atual. Teresina: Embrapa Meio-Norte, 2001. 16p. (Documentos 58)

CERVINI, M.; HENRIQUE-SILVA, F.; MORTARI, N. et al. Genetic variability of 10 microsatellite markers in the characterization of Brazilian Nellore catlle (Bos indicus). Genetics and Molecular Biology, v.29, n.3, p.486-490, 2006.

CHIKHI, L.; GOOSSENS, A.; TREANOR, A. et al. Population genetic structure of and inbreeding in an insular cattle breed, the Jersey, and its implications for genetic resource management. Journal of Heredity, v.92, p.396-401, 2004.

EGITO, A.A. Diversidade genética, ancestralidade individual e miscigenação nas raças bovinas no Brasil com base em microssatélites e haplótipos de DNA mitocondrial: subsídios para a conservação. 2007. 246f. Tese (Doutorado em Biologia Molecular) - Universidade de Brasília, Brasília, Distrito Federal, Brasil.

EGITO,A.A.; PAIVA, S.R.; MAMANÍ, E.M. etal. Variabilidade genética de raças bovinas baseada em marcadores STR. In: SIMPÓSIO DA SOCIEDADE BRASILEIRA DE MELHORAMENTO ANIMAL, 2004, 5., Pirassununga. Anais... João Pessoa: Sociedade Brasileira de Melhoramento Animal, 2004. p.1- 4

EGITO, A.A.; PAIVA, S.R.; ALBUQUERQUE, M.S.M. et al Microsatellite based genetic diversity and relationships among ten Creole and commercial cattle breeds raised in Brazil. BMC Genetics, v.8,p.83, 2007. Available at: $<$ http://www.biomedcentral. com/1471-2156/83> Accessed on: Jan. 11, 2008

El MOUSADIK, A.; PETIT, R.J. High level of genetic differentiation for allelic richness among populations of the argan tree [Argania spinosa (L.) Skeels] endemic to Morocco. Theoretical and Applied Genetics, v.92, p.832-839, 1996.

FOOD AND AGRICULTURE ORGANIZATION OF THE UNITED NATIONS - FAO. Global project for the maintenance of domestic animal genetic diversity. Rome, Italy, 2004. Available at: <http://www.fao.org/dad-is>. Accessed on: Mar. 29, 2006, Nov. 28, 2007 and June 25, 2008.

FRIES, R.; EGGEN, A.; WOMACK, J.E. The bovine map. Mammalian Genome, v.4, p.405-428, 1993.

HEDRICK, P.W. Genetics of populations. 3.ed. Boston: Jones and Bartlett Publishers, 2005. 737p.

HIGUCHI, R. Simple and rapid preparation of samples for PCR. In: ERLICH, H.A. (Ed.) PCR technology: principles and applications for DNA amplification. New York: Stockton Press, 1989. p.31-38.

HURLBERT, S.H. The nonconcept of species diversity: a critique and alternative parameters. Ecology, v.52, p.577-586, 1971.

KIM, K.S.; YEO, J.S.; CHOI, C.B. Genetic diversity of north-east Asian catlle based on microsatellite data. Animal Genetics, v.33, p.201-204, 2002.

LEBERG, P.L. Estimating allelic richness: effects of a sample size and bottlenecks. Molecular Ecology, v.11, p.2445-2449, 2002.

LIRÓN, J.P.; PERAL-GARCÍA, P. et al. Genetic characterization of Argentine and Bolivian Creole cattle breeds assessed through microsatellites. Journal of Heredity, v.97, n.4, p.331-339, 2006.

MAGEE, D.; MEGHEN, C.; HARRISON, S. et al. A partial African ancestry for the creole cattle populations of the Caribbean. Journal of Heredity, v.93, n.6, p.429-432, 2002.

MARIANTE, A.S.; CAVALCANTE, N. Animais do descobrimento: raças domésticas da história do Brasil. 2.ed. Brasília: EMBRAPA, 2006. 228p.

MARIANTE, A.S.; ALBUQUERQUE, M.S.M.; EGITO, A.A. et al. Present status of conservation of livestock genetic resources in Brazil. Livestock Science, v.120, p.204-212, 2009. 
MARSHALL, T.C.; SLATE, J.; KRUUK, L.E.B. et al. Statistical confidence for likelihood-based paternity inference in natural populations. Molecular Ecology, v.7, p.639-655, 1998.

MATEUS, J.C.; PENEDO, M.C.T.; ALVES, V.C. et al. Genetic diversity and diferentiation in Portuguese cattle breeds using microsatellites. Animal Genetics, v.35, p.106-113, 2004.

MAUDET, C.; LUIKART, G.; TABERLET, P. Genetic diversity and assignment tests among seven French catlle breeds based on microsatellites DNA analysis. Journal of Animal Science, v.80, p.942-949, 2002.

MEIRELLES, F.; ROSA A.; LOBO, R. et al. Is the American zebu really Bos indicus? Genetics and Molecular Biology, v.22, n.4, p.543-546, 1999.

MIRETTI, M.M.; PEREIRA, H.A.; POLI, M.A. et al. African derived mitochondria in South American native cattle breeds (Bos taurus): evidence of a new taurine mitochondrial lineage. Journal of Heredity, v.95, p.323-330, 2002.

MIRETTI, M.M.; DUNNER, M. et al. Predominant African-Derived mtDNA in Caribbean and Brazilian Creole Cattle is also found in Spanish Cattle (Bos taurus). Journal of Heredity, v.95, n.5, p.450-453, 2004.

MIROL, P.A.; GIOVAMBATTISTA, G.; LIRON, J.P. et al. African and European mitochondrial haplotypes in South American Creole cattle. Heredity, v.91, p.248-254, 2003.

MOUSADIK, A.E.; PETIT, R.J. High level of genetic differentiation for allelic richness among populations of the argan tree [Argania spinosa (L.) Skeels] endemic to Morocco. Theoretical and Applied Genetics, v.92, p.832-839, 1996.

NEI, M. Molecular evolutionary genetics. New York: Columbia University Press, 1987. 512p.

PEELMAN, L.J.; MORTIAUX, F.; ZEVERAN, A.V. et al. Evaluation of the genetic variability of 23 bovine microsatellite markers in four Belgian catlle breeds. Animal Genetics, v.29, p.161-167, 1998.

PETIT, R.J.; EL MOUSADIK, A.; PONS, O. Identifying populations for conservation on the basis of genetic markers. Conservation Biology, v.12, p.844-855, 1998.
PRIMO, A.T. El ganado bovino ibérico en las Américas: 500 años después. Archivos de Zootecnia, v.41, p.421-432, 1992.

RAYMOND, M.; ROUSSET, F. Genepop (version 2.0): population genetics software for exact tests and ecumenicism. Journal of Heredity, v.86, p.248-249, 1995.

SASTRE, H.J. Descripición, situación atual y estrategias de conservación de la raza bovina colombiana criolla casanare. 2003. 337f. Tesis (Doctorado en Veterinaria) - Departamento de Producción Animal, Facultad de Veterinaria, Universidad de Córdoba, Córdoba, Espanha.

STEFFEN, P.; EGGEN, A.; DIETZ, A.B. et al. Isolation and mapping of polymorphic microsatellites in cattle. Animal Genetics, v.24, p.121-124, 1993.

STONE, R.T.; PULIDO, J.C.; DUYK, G.M. et al. A small-insert bovine genomics library highly enriched for microsatellite repeat sequences. Mammalian Genome, v.6, p.714-724, 1995.

STONE, R.S.; KAPPES, S.M.; BEATTIE, C.W. Five polymorphic trinucleotide (CCA) bovine microsatellites. Animal Genetics, v.27, n.3, p.216, 1996.

SUN, H.S.; BARENDSE, W.; KIRKPATRICK, B.M. "UWCA46" a polymorphic bovine microsatellite marker. Journal of Animal Science, v.73, p.1530, 1995.

TROY, C.S.; DE MACHUGH, J.F.; BAILEY, D.A. et al. Genetic evidence for Near-Eastern origins of European cattle. Nature, v.410, p.1088-1091, 2001.

ULLOA-ARVIZU, R.; GAYOSSO-VÁZQUEZ, A.; RAMOS-KURI, M. et al. Genetic analysis of Mexican Criollo cattle populations. Journal of Animal Breeding and Genetics, v.125, p.351-359, 2008.

VAIMAN, D.; MERCIER, D.; MOAZAMI-GOUDARZI, K. et al. A set of 99 cattle microsatellites: characterization, synteny mapping and polymorphism. Mammalian Genome, v.5, p.288-297, 1994.

WOOLLIAMS, J.A.; MATIKA, O.; PATTISON, J. Conservation of animal genetic resources: approaches and technologies for in situ and ex situ conservation. Animal Genetic Resources, v.42, p.71-89, 2008 . 